Article

\title{
Fluorescence Differentiation of ATP-Related Multiple Enzymatic Activities in Synovial Fluid as a Marker of Calcium Pyrophosphate Deposition Disease Using Kyoto Green
}

\author{
Nattha Yongwattana ${ }^{1}$, Nutsara Mekjinda ${ }^{1}$, Tulyapruek Tawonsawatruk ${ }^{2}$, Itaru Hamachi ${ }^{3}$, \\ Akio Ojida ${ }^{4}$ and Jirarut Wongkongkatep ${ }^{1, *(\mathbb{D})}$ \\ 1 Department of Biotechnology, Faculty of Science, Mahidol University, 272 Rama 6 Road, Bangkok 10400, \\ Thailand; oun.nattha@gmail.com (N.Y.); nutsara.mek@student.mahidol.ac.th (N.M.) \\ 2 Department of Orthopedics, Faculty of Medicine, Ramathibodi Hospital, Mahidol University, 270 Rama 6 \\ Road, Bangkok 10400, Thailand; tulyapruek.tao@mahidol.ac.th \\ 3 Department of Synthetic Chemistry and Biological Chemistry, Graduate School of Engineering, Kyoto \\ University, Kyoto 615-8510, Japan; ihamachi@sbchem.kyoto-u.ac.jp \\ 4 Graduate School of Pharmaceutical Sciences, Kyushu University, 3-1-1 Maidashi, Higashi-ku, Fukuoka \\ 812-8582, Japan; ojida@phar.kyushu-u.ac.jp \\ * Correspondence: jirarut.chu@mahidol.ac.th
}

Received: 29 January 2020; Accepted: 25 February 2020; Published: 2 March 2020

\begin{abstract}
Calcium pyrophosphate deposition disease (CPPD) is a crystal induced inflammation in joints, and causes severe pain in elderly people. The accumulation of pyrophosphate (PPi) in synovial fluid (SF) results from several enzymatic reactions, especially the highly activated e-NPPs, which catalyze the conversion of ATP to PPi. This study demonstrates the detection of relative catalytic activity of 3 enzymes-ecto-nucleotide pyrophosphatase/phosphodiesterases (e-NPPs), tissue nonspecific alkaline phosphatase (TNAP), and ecto-nucleoside triphosphate diphosphohydrolases (e-NTPDases) - using a single molecular sensor called Kyoto Green. Kyoto Green exhibits excellent performance in sensing the catalytic activity of the commercial representatives of the e-NPPs, TNAP, and e-NTPDases, which are ENPP1, PPase, and apyrase, respectively, in both single-enzyme and multi-enzyme assays. Analysis of SF enzymes in 19 SF samples from human and swine revealed moderate activity of e-NPPs, high activity of e-NTPDases, and low activity of TNAP. Our newly developed method for analysis of multiple enzymatic activities using Kyoto Green in biological SF will assist improvement in accuracy of the CPPD prognosis/diagnosis, which will minimize unnecessary medical procedures.
\end{abstract}

Keywords: CPPD; pseudogout; ENPP1; PPase; apyrase; synovial fluid; fluorescence detection; molecular sensor

\section{Introduction}

Articular cartilage calcification is a phenomenon that causes severe pain and inflammation in the joints of elderly individuals, overlapping broadly with osteoarthritis. Among the calcium salts that cause articular cartilage calcification, calcium pyrophosphate dihydrate (CPP) and calcium phosphate are found in over $20 \%$ of population over 60 years of age [1], and in $60 \%$ of patients considering joint arthroplasty [2]. The deposition of CPP crystal in joints is referred to as calcium pyrophosphate deposition disease (CPPD), also known as pseudogout until recently [3]. Despite its reported high prevalence, CPPD is still underdiagnosed due to the lack of an effective diagnosis tool $[2,3]$. Currently, the most accurate indicator of CPPD is the positive birefringence of the CPP crystals in synovial fluid 
from the affected joints [3]; however, the observation of CPP crystals via polarized light microscope is difficult in practice because these crystals are small and often show weak birefringence. Therefore, a more accurate technique to differentiate CPPD from gout and osteoarthritis is needed to help minimize misdiagnosis and increase the quality of life in elderly patients.

Inorganic pyrophosphate (PPi) plays a central role in pathogenesis of pseudogout, analogous to the role of urate in gout. The majority of PPi in cartilage is produced from extracellular ATP (eATP), which is effluxed from chondrocyte and regulated by the multipass membrane protein known as ANKH (Figure 1a) [4,5]. Articular chondrocytes maintain eATP at concentrations between 2 and $4 \mathrm{nM}$ [6]. Extracellular nucleotides are metabolized by a variety of ectoenzymes detected in the plasma membrane, including ecto-nucleotide pyrophosphatase/phosphodiesterases (e-NPPs), tissue nonspecific alkaline phosphatase (TNAP) or inorganic pyrophosphatases (PPases), ecto-nucleoside triphosphate diphosphohydrolases (e-NTPDases), and ecto-5'-nucleotidases (e-5'-NT) [7]. In particular, the e-NPPs family hydrolyzes ATP to AMP, and produces PPi in the process [7]. The released PPi, in conjunction with the high calcium concentration of $2.3 \mathrm{mM}$ in the synovial fluid, can lead to formation of CPP crystals [8]. Derfus et al. (1998) reported that, upon of addition of ATP, matrix vesicles produce abundant CPP crystals $[9,10]$. However, reduction in the amount of CPP crystals was observed when PPases were present, as the enzymes were capable of hydrolyzing PPi at neutral pH [11].

(a)

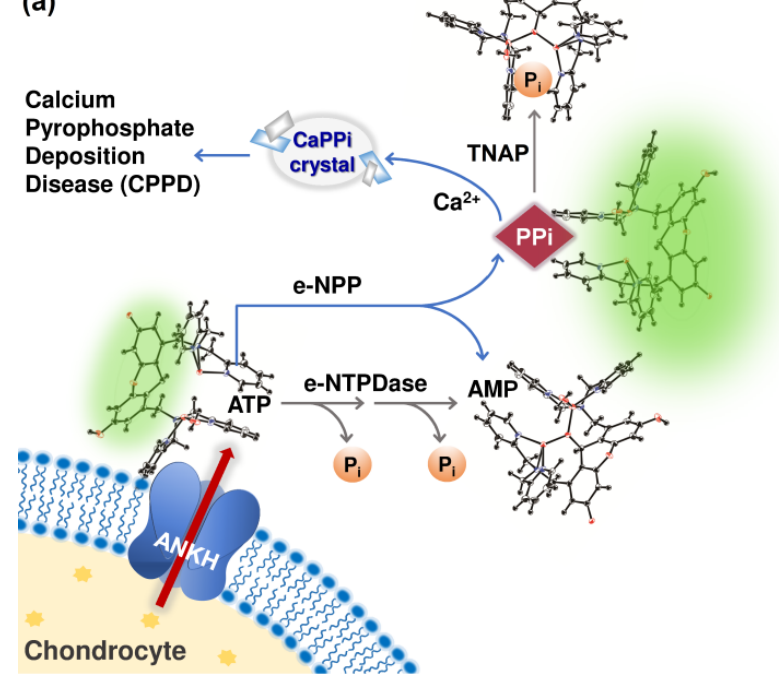

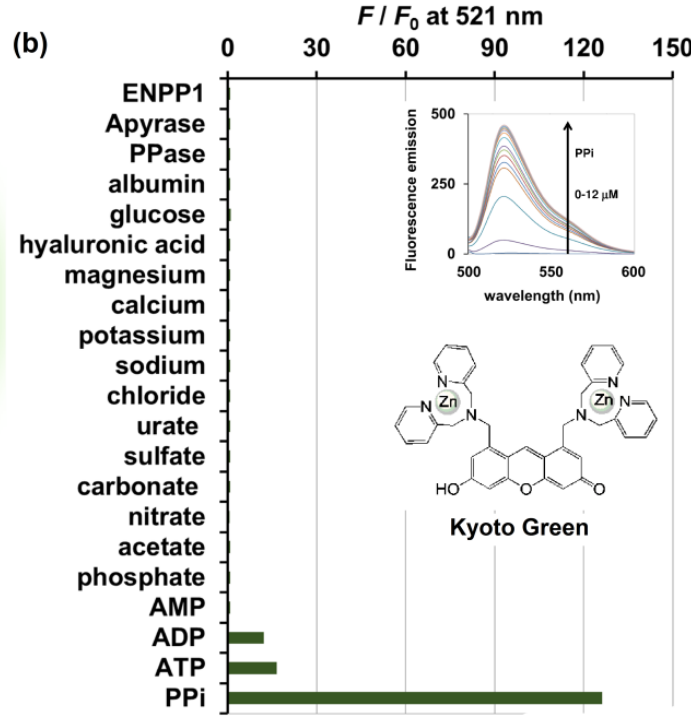

Figure 1. (a) Schematic illustration of ATP conversion pathways occurring in biological synovial fluid differentiated using PPi-specific Kyoto Green; (b) Selectivity of Kyoto Green $(1 \mu \mathrm{M})$ towards various ions $(2 \mu \mathrm{M})$, hyaluronic acid $(3 \mathrm{mg} / \mathrm{mL})$, glucose $(3 \mathrm{mg} / \mathrm{mL})$, albumin $(20 \mathrm{mg} / \mathrm{mL})$, PPase $(0.4 \mathrm{ng} / \mu \mathrm{L})$, apyrase $(4 \mathrm{ng} / \mu \mathrm{L})$, and ENPP1 enzymes $(1 \mathrm{ng} / \mu \mathrm{L})$ commonly found in biological synovial fluids. Measurement conditions: $50 \mathrm{mM}$ HEPES buffer, $10 \mathrm{mM} \mathrm{NaCl}, 1 \mathrm{mM} \mathrm{MgCl} 2$ (pH 7.4, $25{ }^{\circ} \mathrm{C}, \lambda_{\mathrm{ex}}=$ $488 \mathrm{~nm}$ ); (inset, top) Fluorescence emission change of Kyoto Green upon addition of PPi; (inset, bottom) chemical structure of Kyoto Green.

To date, no e-NTPDases have been reported in articular chondrocytes. However, it was reported that movement of joints could mechanically stimulate ATP efflux and trigger the release of NTPdases and e-5'-NT, both of which successively catalyze dephosphorylation of the oncoming ATP into AMP and $\mathrm{Pi}$ [7]. As this pathway competes with e-NPPs for ATP, the abundance of active e-NTPDases in the synovial fluid could be linked to lower PPi accumulation, and in turn less likelihood of CPPD (Figure 1a). On the other hand, high activity of e-NPPs and low activity of PPase will enhance PPi accumulation in synovial fluid. Therefore, the relative activity of e-NPPs, PPase, and eNTPDase in biological fluids could serve as a powerful indicator of the PPi deposition and CPP crystal formation, and ultimately help differentiate CPPD patients from those with gout and osteoarthritis. 
Several ATP detection platforms have been developed and employed to measure the activity of ATP-related enzymes [12-15]. However, these methods were designed to analyze only one enzyme at a time, in highly-defined buffer systems. [16-18]. Herein, we propose a novel strategy for detection of multiple enzymatic activities in biological milieu, using only one small fluorescent molecular probe. The sensor employed, referred hereafter as Kyoto Green, consists of dipicolylamine- $\mathrm{Zn}^{\mathrm{II}}$ as a target binding motif and xanthene as a fluorophore (Figure 1). It has high affinity towards PPi, and to a lesser extent ATP and ADP. Kyoto Green possesses a unique sensing mechanism, in which specific binding to the target triggers reversible cleavage of a covalent bond, leading to a change in optical properties of the sensing domain [19]. Specifically, in the absence of target, the bridging water molecule between the two $\mathrm{Zn}^{2+}$ centers attacks the xanthene ring and disrupts its conjugated $\pi$-system, in effect inhibiting the fluorescence. Upon chelation of the target by the two Zn centers, however, the coordination geometry is reconfigured, resulting in removal of nucleophilic water from the xanthene ring and restoration of its $\pi$-conjugation. First applied as a Turn-ON fluorescent ATP sensor by Ojida and Hamachi et al. [12], Kyoto Green has since been successfully adapted for several bioanalytical applications, including fluorescent assay of hydrolysis pathway of diadenosine tetraphosphate [16], organelle-localized multicolor fluorescence probes for imaging of ATP dynamics in living cells [20], detection of nucleic acid amplification in molecular diagnosis of viral infections [21], detection of pathogenic spore-forming bacteria through the intracellular ATP pool [22], and fluorescent visualization of red blood cell CR1-mediated ATP release [23]. In this work, Kyoto Green was employed for measurement of relative activities of ATP-converting enzymes in synovial fluids, to achieve more accurate differentiation of CPPD, gout, and osteoarthritis.

\section{Results and Discussion}

\subsection{Selectivity and Sensitivity of Kyoto Green}

After efflux from the chondrocyte via the multipass membrane ANKH protein, ATP is hydrolyzed via two pathways: 1) through e-NPP, forming PPi which can be subsequently hydrolyzed to Pi via the activated TNAP; and 2) though e-NTPDase, which converts ATP to ADP and AMP simultaneously (Figure 1a). We began by verifying the fluorescent signal of Kyoto Green toward various molecules that are commonly found in biological fluids. When fluorescence emission was measured at $521 \mathrm{~nm}$, the sensor exhibited the highest response to $2 \mu \mathrm{M}$ of PPi (125-fold increase), and moderate response toward the same concentration of ATP and ADP (16- and 13-fold enhancement, respectively) (Figure 1b and inset). Kyoto Green displayed negligible fluorescence response toward the same concentration of other anions such as phosphate, acetate, nitrate, carbonate, sulfate, urate, and chloride. Other cations such as sodium, potassium, calcium, and magnesium; and other components found in biological synovial fluid including glucose, hyaluronic acid, albumin, ENPP1, apyrase, and PPase also failed to increase fluorescence emission of Kyoto Green (Figure 1b). McMahon et al. (2008) reported the compositions of SF as sodium $(136.1 \mathrm{mM})$, calcium $(1.2 \sim 2.4 \mathrm{mM})$, bicarbonate $(9.7 \sim 15.4 \mathrm{mM})$, and chloride $(107.1 \mathrm{mM})$, together with a small amount of potassium. In addition, SF has $3 \sim 4 \mathrm{~g} / \mathrm{L}$ of hyaluronic acid, $0.7 \sim 1.1 \mathrm{~g} / \mathrm{L}$ of glucose, and the total protein content of $17.2 \mathrm{~g} / \mathrm{L}$, in which $55-70 \%$ represented albumin [8]. As none of these compositions could inhibit or be sensed by Kyoto Green, the sensor will fluoresce intensely only when the PPi-producing e-NPP pathway is highly active, but PPase activity is low. When the inorganic pyrophosphatase (PPase) is highly activated, PPi degradation by PPase yields a non-binding $\mathrm{Pi}$, resulting in the decrease in fluorescence from Kyoto Green. The fluorescence response of Kyoto Green also diminishes when ATP is converted to AMP and Pi via e-NTPDase pathway, as Kyoto Green responds to AMP less strongly than ATP. Thus, the enhancement in $F / F_{0}$ of Kyoto Green could indicate the accumulation of PPi in synovial fluids and a high risk of CPPD, whereas the decrease in fluorescence would suggest that the non-PPi producing pathway dominates the overall ATP conversion, hence a low risk of CPPD. 
2.2. Assay of Ecto-Nucleotide Pyrophosphatase/Phosphodiesterases (e-NPP), Tissue Nonspecific Alkaline Phosphatase (TNAP), and Ecto-Nucleoside Triphosphate Diphosphohydrolases

The e-NPPs consist of three established cell surface enzymes: ENPP1, ENPP2, and ENPP3, all of which convert ATP to PPi and AMP [7]. ENPP1, a type-II transmembrane glycoprotein, is located in the extracellular space of mineralizing cells such as osteoblasts and chondrocytes, and assists in the regulation of bone metabolism [24]. Because Kyoto Green prefers PPi over ATP (Figure 1b), conversion of ATP to PPi should increase the fluorescence emission of Kyoto Green. When $5 \mu$ M of ATP was hydrolyzed by ENPP1, Kyoto Green yielded approximately 50-fold increase in $F / F_{0}$ (Figure 2a). On the other hand, when $5 \mu \mathrm{M}$ ADP was added instead of ATP, the value of $F / F_{0}$ remained almost constant, yielding $\Delta F$ of only +0.01 (Table 1 ), in accordance with the previous finding that showed ADP to be a poor substrate for ENPP1. The initial rates of reaction (i.e., change of fluorescence per min) increased linearly with the amount of ENPP1 added (Figure 2a inset), suggesting that the kinetics of ENPP1 could be studied in one pot with Kyoto Green as a reporter and natural ATP as a substrate.

(a)

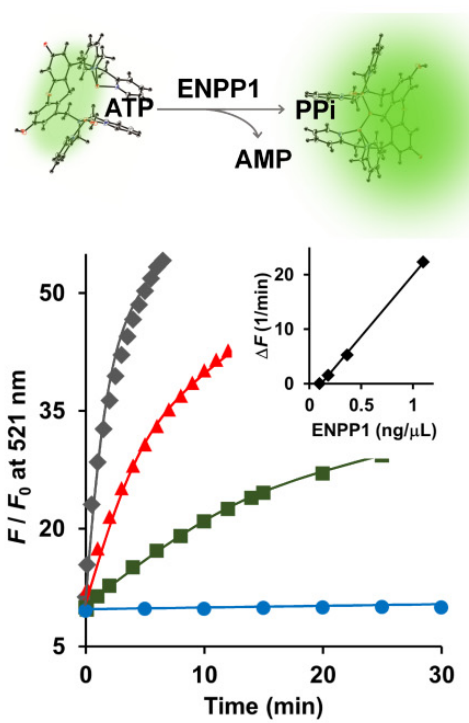

(b)
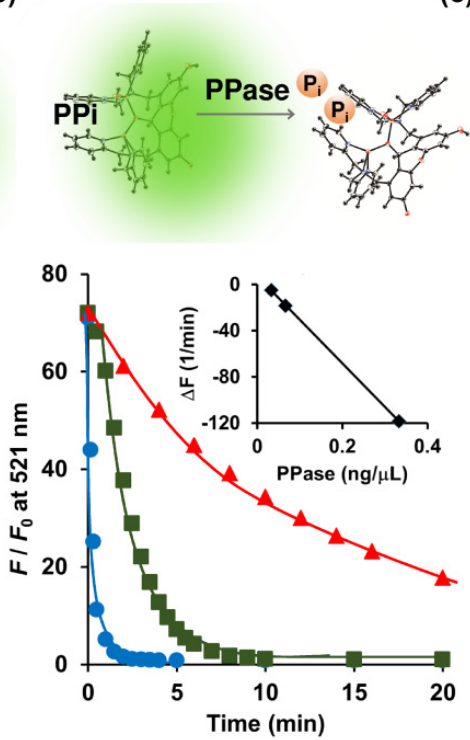

(c)
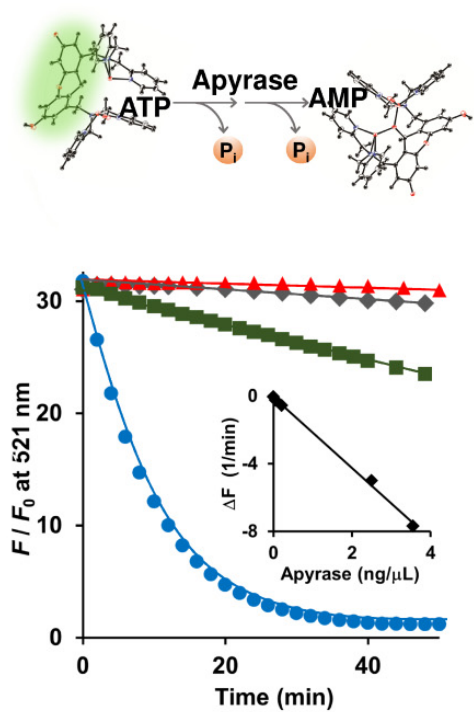

Figure 2. (a) Conversion of ATP $(5 \mu \mathrm{M})$ to PPi catalyzed by ENPP1; (b) Degradation of PPi $(1 \mu \mathrm{M})$ to Pi catalyzed by inorganic PPase; (c) Hydrolysis of ATP $(2 \mu \mathrm{M})$ to AMP catalyzed by apyrase monitored real-time in a $0.7-\mathrm{mL}$ cuvette by $1 \mu \mathrm{M}$ Kyoto Green. Measurement conditions: $50 \mathrm{mM}$ HEPES buffer, $10 \mathrm{mM} \mathrm{NaCl}, 1 \mathrm{mM} \mathrm{MgCl} 2\left(\mathrm{pH} 7.4,25^{\circ} \mathrm{C}, \lambda_{\mathrm{ex}}=488 \mathrm{~nm}\right)$.

Table 1. Maximum fluorescence change $(\Delta F)$ of Kyoto Green in real-time monitoring of ENPP1, PPase, and apyrase activities.

\begin{tabular}{cccc}
\hline Substrate & ENPP1 & PPase & Apyrase \\
\hline ATP & +48.72 & -0.84 & -30.58 \\
ADP & +0.01 & -0.89 & -16.29 \\
PPi & product $^{1}$ & -70.18 & -0.03 \\
\hline
\end{tabular}

${ }^{1} \mathrm{PPi}$ is the product of ATP hydrolysis catalyzed by ENPP1.

Nakagawa et al. (2019) reported the ENPP1 assay based on the Tokyo Green fluorescent dye conjugated with mAMP as a substrate [25]. The conventional ENPP1 assay employs $p$-nitrophenyl 5'-thymidine monophosphate ( $p$-Nph-5'-TMP) as a substrate [26,27]. However, Namasivayam et al. (2017) argued that unmodified ATP serves as a better substrate than its derivatized counterpart, $p$-Nph-5'-TMP, because the specificity constant $\left(k_{\mathrm{cat}} / K_{\mathrm{M}}\right)$ value of ATP was 6.74-fold higher than that of $p$-Nph-5'-TMP [28]. Furthermore, Lee et al. (2017) also found that $p$-Nph-5'-TMP may also function as 
an allosteric modulator of ENPP1 by binding to its allosteric site and inducing a conformational change of the active site [29]. Therefore, by directly measuring ATP in its natural form, our Kyoto Green-based ENPP1 assay offers a more accurate way of quantifying ENPP1 activity, free from complications due to chemical derivatization and allosteric modulation.

During calcification of human cartilage, the generated PPi is further hydrolyzed by TNAP to $\mathrm{Pi}$, which is involved in the formation of hydroxyapatite. Lower activity of TNAP will result in the build-up of PPi in the cartilage, posing a higher risk for CPPD. To this end, we sought to investigate whether Kyoto Green can be used to monitor TNAP-catalyzed depletion of PPi in real time. Addition of PPase, a member in TNAP family, to the mixture of PPi and Kyoto Green progressively reduced the fluorescence intensity (Figure $2 b$ ). The initial rates of the reaction changed in a linear proportion to the amount of the PPase employed (Figure $2 b$ inset). In contrast, the inorganic PPase exhibited no catalytic activity when ATP and ADP were added as a substrate (Table 1). Taken together, these findings demonstrate that Kyoto Green can serve as an effective indicator in real-time PPase assay.

Following its efflux from chondrocytes, ATP can be hydrolyzed to ADP and AMP by e-NTPDase. Since Kyoto Green produces moderate fluorescence in response to ATP, e-NTPDase-mediated ATP hydrolysis should lead to reduction in $F / F_{0}$. Apyrase, a member of the e-NTPDase family, was used as the surrogate for the SF-derived e-NTPDase in this study. Indeed, the addition of apyrase to the ATP-Kyoto Green mixture caused the fluorescence to reduce over time, as shown in Figure 2c. Furthermore, initial reduction rates of $F / F_{0}$ were in linear relationship with the amount of apyrase added (Figure 2c, inset). Thus, in addition to ENPP1 and PPase, Kyoto Green was also capable of tracking the activity of apyrase.

\subsection{Relative Activity of ENPP1, Apyrase, and PPase}

Several molecular sensors have been developed to monitor catalysis by alkaline phosphatase, PPase, and apyrase in real time [13,30-34]. However, a platform that can detect the activity of more than one enzyme from this group simultaneously is not yet available. Since Kyoto Green had exhibited an excellent response towards each of these enzymes [16], we proceeded to evaluate its performance in a multi-enzyme assay.

Enzymatic conversion of ATP by the combination of ENPP1 and apyrase was monitored in real time by Kyoto Green. Theoretically, active ENPP1 should enhance fluorescence emission at $521 \mathrm{~nm}$ due to production of PPi, whereas dephosphorylation of ATP into AMP and Pi by apyrase was expected to reduce the signal. When $0.73 \mathrm{ng} / \mu \mathrm{L}$ ENPP1 was mixed with $5.0 \mathrm{ng} / \mu \mathrm{L}$ of apyrase, overall $F / F_{0}$ increased over time, indicating that ENPP1-catalyzed PPi production was predominant. Conversely, increasing apyrase concentration to $10.0 \mathrm{ng} / \mu \mathrm{L}$, while fixing ENPP1 at $0.73 \mathrm{ng} / \mu \mathrm{L}$, led to suppression of $F / F_{0}$ (Figure $\left.3 a\right)$, suggesting that apyrase outperformed ENPP1.

Additionally, Kyoto Green was also used to monitor reactions in which both ENPP1 and PPase were present. A reaction containing $1.1 \mathrm{ng} / \mu \mathrm{L}$ ENPP1 and $50 \mu \mathrm{M}$ of ATP was allowed to proceed for $1 \mathrm{~h}$, before PPase was added. Upon addition of PPase, $F / F_{0}$ began to decline sharply (Figure $3 b$ ). Decrease of $F / F_{0}$ was also observed when PPase was present from the beginning, although the change was more gradual, possibly because PPi generated by ENPP1 was immediately consumed by PPase and never allowed to build up (Figure 3b). Collectively, these results demonstrate that, by monitoring real-time changes in fluorescence, Kyoto Green could offer insight on the relative activities of enzymes. 
(a)
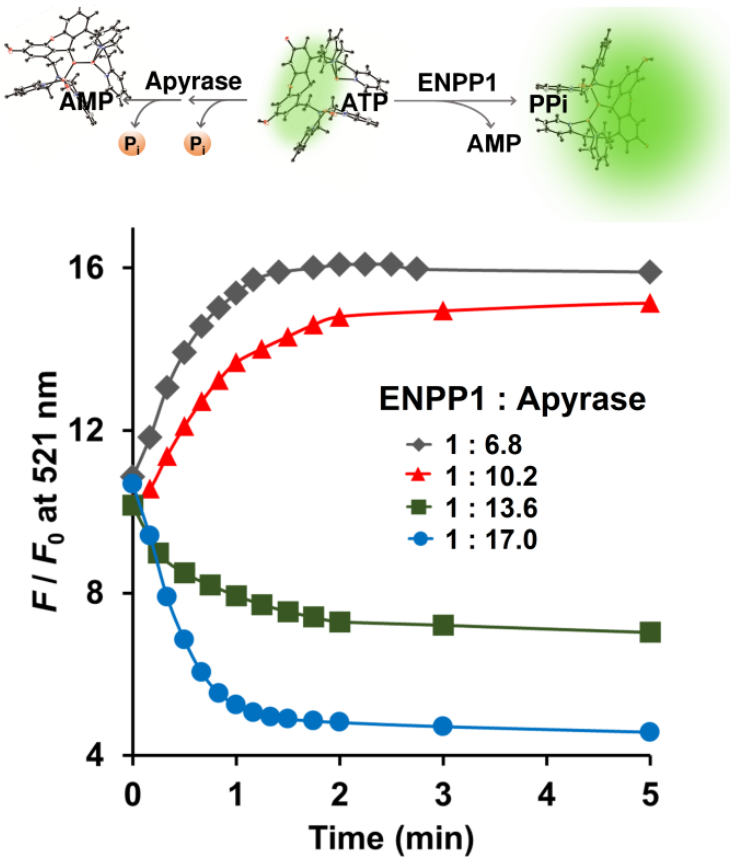

(b)
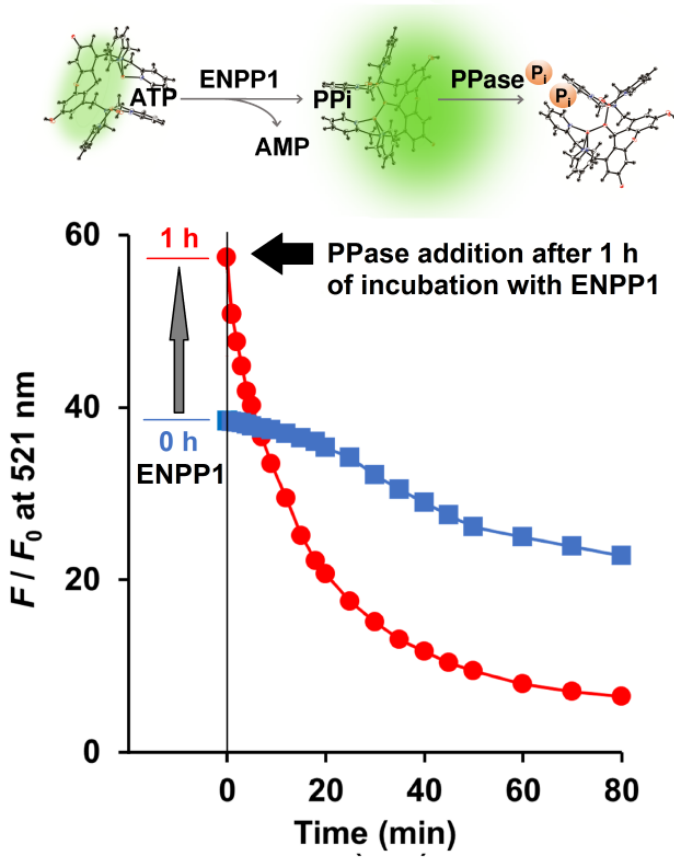

Figure 3. (a) Competitive catalytic activity of ENPP1 $(0.734 \mathrm{ng} / \mu \mathrm{L})$ and apyrase $(5.0,7.5,10.0$ and $12.5 \mathrm{ng} / \mu \mathrm{L}$ ) toward $5 \mu \mathrm{M}$ ATP monitored in real time by $1 \mu \mathrm{M}$ Kyoto Green; (b) Catalytic activity of ENPP1 $(1.1 \mathrm{ng} / \mu \mathrm{L})$ when $50 \mu \mathrm{M}$ of ATP was used as a substrate. PPase $(0.03 \mathrm{ng} / \mu \mathrm{L})$ was added at 0 (blue square) and $1 \mathrm{~h}$ (red circle) after ENPP1 addition. Measurement conditions: $50 \mathrm{mM}$ HEPES buffer, $10 \mathrm{mM} \mathrm{NaCl}, 1 \mathrm{mM} \mathrm{MgCl} 2\left(\mathrm{pH} 7.4,25^{\circ} \mathrm{C}, \lambda_{\mathrm{ex}}=488 \mathrm{~nm}\right)$.

\subsection{PPi Accumulation Possibility in Biological Fluid}

To test Kyoto Green's ability to analyze clinical samples, the sensor was applied to 19 SF samples collected from human and swine as a proof of principle. The SF samples were mixed with the buffer (50 mM HEPES buffer, pH 7.4, containing $1 \mathrm{mM}$ ATP) in the ratio of 1:4 (v/v) SF: buffer. Each mixture was diluted 1000-fold into the Kyoto Green solution, and their $F / F_{0}$ values after 0 and $24 \mathrm{~h}$ of incubation were recorded (Figure 4). Using the equations as summarized in Table 2, enzymatic activities were then calculated from the $F / F_{0}$ data (Table 3). The $F / F_{0}$ ratio of Kyoto Green at $24 \mathrm{~h}$ is calculated on the basis of its $F / F_{0}$ ratio at $0 \mathrm{~h}$ and then converted into percentage change. A positive sign in percentage change-i.e., an increase in $F / F_{0}$ ratio from 0 th to 24 th $\mathrm{h}$-indicates the predominance of e-NPPs in SF, whereas a negative sign suggests that e-NTPDases dominate. Analysis of SF sample No. 1 revealed a $44.51 \%$ decrease of $F / F_{0}$ from the 0 th to 24 th $h$, which suggests that e-NTPDases were the most active enzymes (Figure $4 a, b)$. Percentage changes of $F / F_{0}$ in samples No. 5, 10 and 11 were slightly positive, indicating that e-NPPs contributed most to the trend. The remaining 16 samples exhibited a large decrease in $F / F_{0}$, suggesting that the key metabolic activity in these samples came from e-NTPDases (Table 3).

To validate our interpretations about relative enzymatic activities, reactions were spiked with commercial PPase or apyrase to deplete PPi or ATP, respectively. Addition of PPase to the assay solution of sample No. 1 did not alter $F / F_{0}$ at $0 \mathrm{~h}$, suggesting that there was no PPi in the solution (Figure $4 \mathrm{a}$ ). However, after $24 \mathrm{~h}$ of incubation, the addition of PPase resulted in a decrease in $F / F_{0}$ of Kyoto Green over time, indicating that the sample exhibited high propensity for PPi formation (Table 3). The values of PPi formation propensity lower than 5 were interpreted as low risk of PPi formation in SF, symbolized by a minus sign in the Table 2. 


\section{(a) PPi formation}
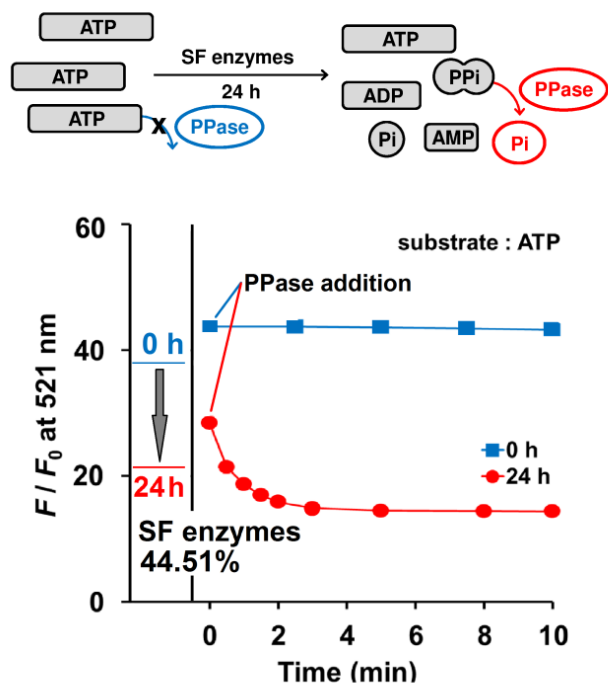

(c) ADP conversion
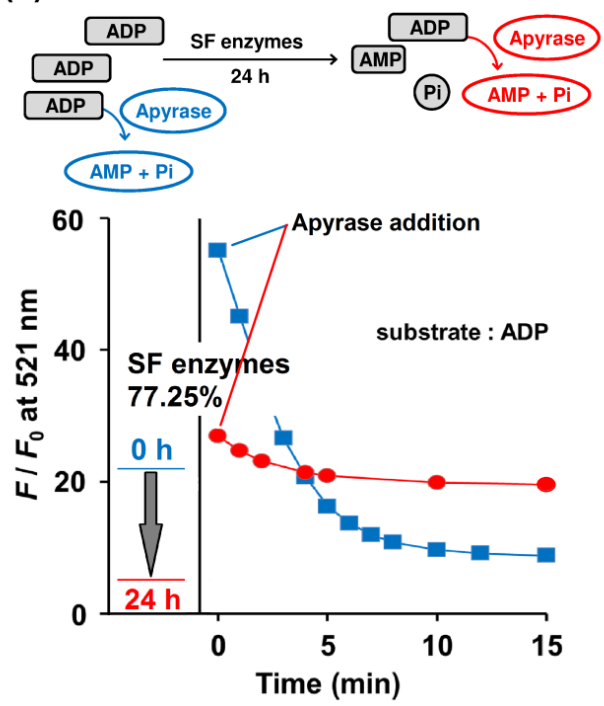

(b) ATP conversion

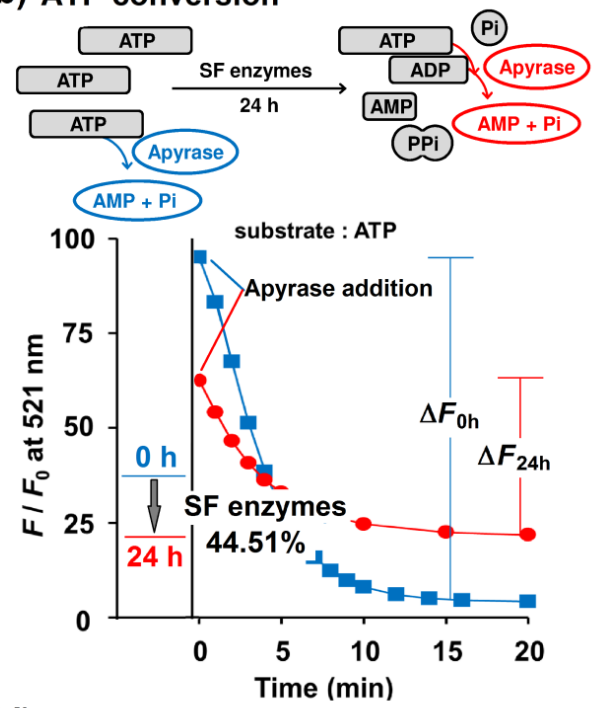

(d) PPi conversion
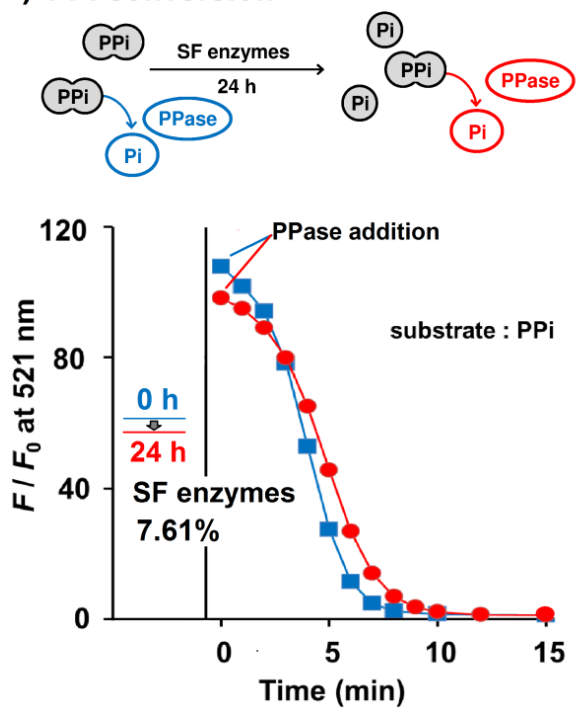

Figure 4. Enzymatic activities of SF No. 1 when $1 \mathrm{mM}$ ATP (a, b), $1 \mathrm{mM}$ ADP (c), and $1 \mathrm{mM} \mathrm{PPi} \mathrm{(d)}$ were employed as a substrate, as reported by Kyoto Green $(1 \mu \mathrm{M})$. The $F / F_{0}$ values of Kyoto Green at $0^{\text {th }}$ and $24^{\text {th }} \mathrm{h}$ after incubation of the substrate with $\mathrm{SF}$, are displayed as a blue and red line, respectively. The incubated mixtures at 0th (blue square) and 24th $\mathrm{h}$ (red circle) were 100-fold diluted and further treated with $0.074 \mathrm{ng} / \mu \mathrm{L}$ PPase $(\mathbf{a}, \mathbf{d})$ and $0.33 \mathrm{ng} / \mu \mathrm{L}$ apyrase $(\mathbf{b}, \mathbf{c})$ then monitored by Kyoto Green $(1 \mu \mathrm{M})$. Measurement conditions: $50 \mathrm{mM}$ HEPES buffer $\left(\mathrm{pH} 7.4,25^{\circ} \mathrm{C}, \lambda_{\mathrm{ex}}=488 \mathrm{~nm}\right)$.

When sample No. 1 was treated with apyrase immediately after mixing with Kyoto Green (i.e., at $0^{\text {th }} \mathrm{h}$ of incubation), $F / F_{0}$ dropped significantly, as indicated by the large $\Delta F_{0 \mathrm{~h}}$ value. Addition of apyrase after $24 \mathrm{~h}$ of incubation reduced $F / F_{0}$ to a lesser extent $\left(\Delta F_{24 \mathrm{~h}}\right)$, which suggests that $S F$ enzymes had partially consumed ATP during the $24 \mathrm{~h}$ incubation, leaving less substrate for apyrase (Figure $4 \mathrm{~b}$ ). The percentages of ATP conversion in all samples were calculated according to the equation in Table 2, and the obtained values are summarized in Table 3. We proposed that an ATP conversion of less than $25 \%$ should be interpreted as indicating low activity of e-NTPDases, as represented by a negative sign, while a value over $75 \%$ would suggest a very high activity (triple positive sign) (Table 2 ). When the proposed criteria were applied to 19 SF samples investigated, 8 samples were found to exhibit low NTPDases activity, whereas 3 samples had highly active NTPDases (Table 3 ). 
Table 2. Equations and criteria used for calculation of SF enzymatic activities.

\begin{tabular}{|c|c|c|c|c|}
\hline Enzymatic Reactions & Equations & Criteria & Symbols & Interpretation \\
\hline $\mathrm{ATP} \rightarrow(\mathrm{SF}$ enzymes $)$ & \multirow{2}{*}{$100 \times\left[\left(F / F_{0}\right)_{24 h} /\left(F / F_{0}\right)_{0 h}-1\right]$} & \multirow{2}{*}{ Percentage change } & + & $\begin{array}{c}\mathrm{e}-\mathrm{NPPs} \\
\text { predominance }\end{array}$ \\
\hline $\begin{array}{c}\mathrm{ADP} \rightarrow(\mathrm{SF} \text { enzymes }) \\
\mathrm{PPi} \rightarrow(\mathrm{SF} \text { enzymes })\end{array}$ & & & - & $\begin{array}{l}\text { e-NTPDases } \\
\text { predominance }\end{array}$ \\
\hline PPi formation ${ }^{1}$ & $\Delta F_{24 \mathrm{~h}} / \Delta F_{0 \mathrm{~h}}$ & $\begin{array}{c}<5 \\
5-10 \\
11-20 \\
>20\end{array}$ & $\begin{array}{c}- \\
+ \\
+ \\
++ \\
+++\end{array}$ & $\begin{array}{l}\text { Low PPi formation } \\
\text { High PPi formation }\end{array}$ \\
\hline $\begin{array}{c}\mathrm{ATP}^{2} / \mathrm{ADP}^{2} / \mathrm{PPi}^{1} \\
\text { conversion }\end{array}$ & $1-\left[\Delta F_{24 h} / \Delta F_{0 h}\right]$ & $\begin{array}{c}<0.25 \\
0.25-0.50 \\
0.50-0.75 \\
>0.75\end{array}$ & $\begin{array}{c}- \\
+ \\
++ \\
+++\end{array}$ & Low activity \\
\hline
\end{tabular}

${ }^{1}$ confirmed by PPase. ${ }^{2}$ confirmed by apyrase.

Table 3. ATP-related enzymatic reactions in synovial fluids. The values listed were calculated using the equations summarized in Table 2. The data are arranged from highest to lowest PPi formation.

\begin{tabular}{|c|c|c|c|c|c|c|c|c|}
\hline \multicolumn{2}{|c|}{ Substrate } & \multicolumn{3}{|c|}{ ATP } & \multicolumn{2}{|c|}{ ADP } & \multicolumn{2}{|c|}{ PPi } \\
\hline No. & Source & SF Enzymes & $\begin{array}{c}\text { PPi } \\
\text { Formation }\end{array}$ & $\begin{array}{c}\text { ATP } \\
\text { Conversion }\end{array}$ & SF Enzymes & $\begin{array}{c}\text { ADP } \\
\text { Conversion }\end{array}$ & SF Enzymes & $\begin{array}{c}\text { PPi } \\
\text { Conversion }\end{array}$ \\
\hline 1 & Human & $-44.51 \pm 4.25$ & $\begin{array}{c}26.01 \pm 1.48 \\
+++\end{array}$ & $\begin{array}{c}0.53 \pm 0.10 \\
++\end{array}$ & $-77.25 \pm 4.63$ & $\begin{array}{c}0.83 \pm 0.13 \\
+++\end{array}$ & $-7.61 \pm 0.21$ & $\begin{array}{c}0.09 \pm 0.07 \\
-\end{array}$ \\
\hline 2 & Swine & $-50.22 \pm 6.39$ & $\begin{array}{c}23.06 \pm 5.96 \\
+++\end{array}$ & $\begin{array}{c}0.46 \pm 0.07 \\
+\end{array}$ & $-62.89 \pm 4.76$ & $\begin{array}{c}0.51 \pm 0.18 \\
++\end{array}$ & $-11.07 \pm 1.47$ & $\begin{array}{c}-0.09 \pm 0.05 \\
-\end{array}$ \\
\hline 3 & Swine & $-70.61 \pm 0.41$ & $\begin{array}{c}22.68 \pm 2.06 \\
+++\end{array}$ & $\begin{array}{c}0.56 \pm 0.02 \\
++\end{array}$ & $-84.79 \pm 1.25$ & $\begin{array}{c}1.00 \pm 0.01 \\
+++\end{array}$ & $-41.50 \pm 9.39$ & $\begin{array}{c}0.19 \pm 0.14 \\
-\end{array}$ \\
\hline 4 & Swine & $-59.64 \pm 3.82$ & $\begin{array}{c}14.91 \pm 1.64 \\
++\end{array}$ & $\begin{array}{c}0.52 \pm 0.11 \\
++\end{array}$ & $-80.82 \pm 6.16$ & $\begin{array}{c}0.68 \pm 0.18 \\
++\end{array}$ & $+36.43 \pm 2.21$ & $\begin{array}{c}0.03 \pm 0.01 \\
-\end{array}$ \\
\hline 5 & Swine & $+1.27 \pm 0.25$ & $\begin{array}{c}12.73 \pm 0.19 \\
++\end{array}$ & $\begin{array}{c}-0.30 \pm 0.17 \\
-\end{array}$ & $-24.36 \pm 2.91$ & $\begin{array}{c}-0.09 \pm 0.13 \\
-\end{array}$ & $+35.12 \pm 3.58$ & $\begin{array}{c}-0.11 \pm 0.03 \\
-\end{array}$ \\
\hline 6 & Human & $-18.17 \pm 0.27$ & $\begin{array}{c}11.20 \pm 0.11 \\
++\end{array}$ & $\begin{array}{c}0.22 \pm 0.03 \\
-\end{array}$ & $-37.27 \pm 2.85$ & $\begin{array}{c}0.31 \pm 0.05 \\
+\end{array}$ & $+8.52 \pm 0.07$ & $\begin{array}{c}-0.03 \pm 0.00 \\
-\end{array}$ \\
\hline 7 & Swine & $-62.68 \pm 5.24$ & $\begin{array}{c}9.07 \pm 0.10 \\
+\end{array}$ & $\begin{array}{c}0.42 \pm 0.03 \\
+\end{array}$ & $-96.10 \pm 9.98$ & $\begin{array}{c}1.00 \pm 0.17 \\
+++\end{array}$ & $-43.29 \pm 3.57$ & $\begin{array}{c}0.12 \pm 0.01 \\
-\end{array}$ \\
\hline 8 & Swine & $-83.83 \pm 3.67$ & $\begin{array}{c}5.14 \pm 1.02 \\
+\end{array}$ & $\begin{array}{c}0.75 \pm 0.17 \\
\quad+++\end{array}$ & $-94.64 \pm 6.41$ & $\begin{array}{c}1.00 \pm 0.09 \\
+++\end{array}$ & $-62.10 \pm 3.52$ & $\begin{array}{c}0.24 \pm 0.01 \\
-\end{array}$ \\
\hline 9 & Swine & $-17.2 \pm 4.01$ & $\begin{array}{c}4.99 \pm 2.39 \\
-\end{array}$ & $\begin{array}{c}0.19 \pm 0.03 \\
-\end{array}$ & $-47.85 \pm 3.50$ & $\begin{array}{c}-0.21 \pm 0.07 \\
-\end{array}$ & $-57.70 \pm 7.77$ & $\begin{array}{c}0.23 \pm 0.18 \\
-\end{array}$ \\
\hline 10 & Human & $+8.95 \pm 7.60$ & $\begin{array}{c}4.95 \pm 0.02 \\
-\end{array}$ & $\begin{array}{c}0.08 \pm 0.00 \\
-\end{array}$ & $-16.36 \pm 2.16$ & $\begin{array}{c}0.17 \pm 0.01 \\
-\end{array}$ & $+0.25 \pm 0.02$ & $\begin{array}{c}-0.16 \pm 0.02 \\
-\end{array}$ \\
\hline 11 & Swine & $+4.46 \pm 0.20$ & $\begin{array}{c}3.81 \pm 0.16 \\
-\end{array}$ & $\begin{array}{c}0.14 \pm 0.01 \\
-\end{array}$ & $-47.10 \pm 3.75$ & $\begin{array}{c}0.06 \pm 0.00 \\
-\end{array}$ & $-1.56 \pm 0.52$ & $\begin{array}{c}0.07 \pm 0.01 \\
-\end{array}$ \\
\hline 12 & Swine & $-91.78 \pm 8.73$ & $\begin{array}{c}3.58 \pm 0.04 \\
-\end{array}$ & $\begin{array}{c}0.86 \pm 0.04 \\
+++\end{array}$ & $-96.84 \pm 6.89$ & $\begin{array}{c}1.00 \pm 0.12 \\
+++\end{array}$ & $-7.14 \pm 0.077$ & $\begin{array}{c}0.19 \pm 0.01 \\
-\end{array}$ \\
\hline 13 & Human & $-12.15 \pm 2.36$ & $\begin{array}{c}2.88 \pm 0.05 \\
-\end{array}$ & $\begin{array}{c}-0.55 \pm 0.02 \\
-\end{array}$ & $-21.44 \pm 2.11$ & $\begin{array}{c}-0.21 \pm 0.06 \\
-\end{array}$ & $+7.55 \pm 0.96$ & $\begin{array}{c}-0.08 \pm 0.02 \\
-\end{array}$ \\
\hline 14 & Human & $-13.85 \pm 2.52$ & $\begin{array}{c}1.93 \pm 0.01 \\
-\end{array}$ & $\begin{array}{c}-0.23 \pm 0.01 \\
-\end{array}$ & $-32.06 \pm 2.96$ & $\begin{array}{c}-0.13 \pm 0.01 \\
-\end{array}$ & $-3.96 \pm 0.17$ & $\begin{array}{c}-0.06 \pm 0.01 \\
-\end{array}$ \\
\hline 15 & Swine & $-81.72 \pm 6.29$ & $\begin{array}{c}1.00 \pm 0.02 \\
-\end{array}$ & $\begin{array}{c}0.59 \pm 0.03 \\
++\end{array}$ & $-95.67 \pm 8.56$ & $\begin{array}{c}1.00 \pm 0.08 \\
+++\end{array}$ & $-84.74 \pm 9.21$ & $\begin{array}{c}0.76 \pm 0.06 \\
+++\end{array}$ \\
\hline 16 & Human & $-67.56 \pm 2.11$ & $\begin{array}{c}0.55 \pm 0.01 \\
-\end{array}$ & $\begin{array}{c}0.46 \pm 0.07 \\
+\end{array}$ & $-94.44 \pm 9.21$ & $\begin{array}{c}1.00 \pm 0.11 \\
+++\end{array}$ & $-7.25 \pm 0.058$ & $\begin{array}{c}-0.01 \pm 0.00 \\
-\end{array}$ \\
\hline 17 & Human & $-11.36 \pm 3.46$ & $\begin{array}{c}0.51 \pm 0.01 \\
-\end{array}$ & $\begin{array}{c}0.09 \pm 0.02 \\
-\end{array}$ & $-35.31 \pm 5.47$ & $\begin{array}{c}0.12 \pm 0.01 \\
-\end{array}$ & $-52.72 \pm 4.27$ & $\begin{array}{c}0.17 \pm 0.01 \\
-\end{array}$ \\
\hline 18 & Swine & $-97.67 \pm 4.93$ & $\begin{array}{c}0.46 \pm 0.03 \\
-\end{array}$ & $\begin{array}{c}1.00 \pm 0.09 \\
+++\end{array}$ & $-95.78 \pm 6.32$ & $\begin{array}{c}1.00 \pm 0.13 \\
+++\end{array}$ & $-77.79 \pm 9.88$ & $\begin{array}{c}0.27 \pm 0.02 \\
+\end{array}$ \\
\hline 19 & Human & $-88.51 \pm 5.65$ & $\begin{array}{c}0.12 \pm 0.00 \\
-\end{array}$ & $\begin{array}{c}0.74 \pm 0.14 \\
++\end{array}$ & $-94.06 \pm 7.85$ & $\begin{array}{c}0.99 \pm 0.11 \\
+++\end{array}$ & $+4.27 \pm 0.46$ & $\begin{array}{c}0.01 \pm 0.00 \\
-\end{array}$ \\
\hline
\end{tabular}

By following similar experimental procedures and calculations as established for ATP, ADP can also be used for assessing overall enzymatic activities in the SF. Table 3 reveals that the ADP conversion by SF enzymes displayed highly negative values, supporting the presence of highly active NTPDases in the SF samples. The results also imply poor efficiency of e-NPPs in converting ADP to PPi. The apyrase assay also shows moderate to high degrees of ADP conversion in 12 out of 19 SF samples, which suggests the presence of active e-NTPDases in the SF. (Table 3). 
Similarly, the percentage of PPi conversion could be calculated by comparing the amounts of PPi before and after $24 \mathrm{~h}$ of SF enzymatic reaction. PPi abundance at each time point was determined by a PPase assay. In human SF No. 1, the PPi conversion of only 7.61\% was observed and the subsequent addition of PPase also yielded comparable $\Delta F_{0 \mathrm{~h}}$ and $\Delta F_{24 \mathrm{~h}}$ (Figure $4 \mathrm{~d}$ ). The presence of active TNAP enzymes in the SF is critical because it can reduce the PPi accumulation and in turn the likelihood of CPPD deposition in the joints. Unfortunately, the degree of PPi conversion in 17 of 19 samples was less than 25\%. It is also apparent from Table 3 that the PPi formed in Sample No. 1-8 would not have been further degraded to Pi due to the low PPase activity in the SF, which implies a high chance of CPPD. The low activity of PPase in SF of adult and elderly people was also suggested by Stefan et al. (2005) [35].

\section{Materials and Methods}

\subsection{Materials}

Kyoto Green $\left(\mathrm{C}_{39} \mathrm{H}_{34} \mathrm{~N}_{6} \mathrm{O}_{4} \mathrm{Zn}_{2} \cdot 2 \mathrm{ClO}_{4}\right)$ was synthesized following Ojida et al [12]. Magnesium chloride $\left(\mathrm{MgCl}_{2}\right)$ was obtained from Merck (Darmstadt, Germany). Sodium chloride $(\mathrm{NaCl})$ was obtained from LobaChemie (Mumbai, India). HEPES $\left(\mathrm{C}_{8} \mathrm{H}_{18} \mathrm{~N}_{2} \mathrm{O}_{4} \mathrm{~S}\right)$, sodium pyrophosphate decahydrate (NaPPi), adenosine, 5'-triphosphate disodium salt (ATP), adenosine 5'-diphosphate disodium (ADP), adenosine 3'-monophosphate (AMP), Apyrase from potatoes was obtained from Sigma-Aldrich Co. (St. Louis, MO, USA). Inorganic pyrophosphatase from yeast (PPase) was purchased from Roche, Rotkreuz, Switzerland. Recombinant Human ENPP1 was purchased from R\&D Systems (Minneapolis, MN, USA).

Swine SF samples were obtained from the hind legs of 90-120 kg adult healthy dead pigs from a local slaughter house (Betagro Public Company, Banglen, Nakhon Pathom, Thailand). SF was removed from the knee joint, located $22 \mathrm{~cm}$ away from the end of the leg, with a 20 gauge needle at approximately $1 \mathrm{~h}$ after death. The samples were stored at $-20^{\circ} \mathrm{C}$ until further use.

Human SF samples were kindly provided by Asst. Prof. Dr. Tulyapruek Tawonsawatruk, Department of Orthopedics, Faculty of Medicine, Ramathibodi Hospital, Mahidol University, Bangkok, Thailand. These samples were left over from the therapeutic treatment of patients with joint inflammation and display no signs of bacterial infection. The obtained human SF samples were used after ethical approval from Ramathibodi Hospital, Mahidol University, Bangkok, Thailand (Documentary Proof of Ethical Clearance Committee on Human Rights Related to Research Involving Human Subjects, based on the declaration of Helsinki, Faculty of Medicine Ramathibodi Hospital, Mahidol University Reference No. MURA2017/317).

The swine SF and human SF samples were pipetted into Eppendorf tubes and centrifuged at $12,000 \mathrm{rpm}(9660 \times g)$ for 10 minutes for separation of supernatant and precipitate (WiseSpin CF-10, Daihan Scientific, Gangwon-do, South Korea). The clear supernatant of SF in the upper phase was stored at $-20{ }^{\circ} \mathrm{C}$ prior to analysis.

\subsection{Selectivity and Sensitivity of Kyoto Green}

The aqueous solution of PPi was serially titrated into a solution ( $3 \mathrm{~mL}$ ) of $1 \mu \mathrm{M}$ Kyoto Green, containing $50 \mathrm{mM}$ HEPES buffer, $10 \mathrm{mM} \mathrm{NaCl}, 1 \mathrm{mM} \mathrm{MgCl}$, pH 7.4 in a quartz cell at $25^{\circ} \mathrm{C}$. The final concentrations of PPi were between 0.001 and $12 \mu \mathrm{M}$. Changes in fluorescence emission from Kyoto Green $(1 \mu \mathrm{M})$ upon the addition of various anions $(2 \mu \mathrm{M})$, hyaluronic acid $(3 \mathrm{mg} / \mathrm{mL})$, glucose $(3 \mathrm{mg} / \mathrm{mL})$, albumin $(20 \mathrm{mg} / \mathrm{mL})$, PPase $(0.5 \mathrm{ng} / \mu \mathrm{L})$, apyrase $(4 \mathrm{ng} / \mu \mathrm{L})$, and ENPP1 enzymes $(1 \mathrm{ng} / \mu \mathrm{L})$ were measured with a spectrofluorometer (JASCO FP6500, Tokyo, Japan), using excitation wavelength of $488 \mathrm{~nm}\left(25^{\circ} \mathrm{C}\right)$. 


\subsection{Assay of ENPP1, PPase, and Apyrase}

To a solution of Kyoto Green $(1 \mu \mathrm{M})$ in $50 \mathrm{mM}$ HEPES buffer, $10 \mathrm{mM} \mathrm{NaCl}, 1 \mathrm{mM} \mathrm{MgCl}$, pH 7.4 placed in a quartz cell, one of the following substrates was added: ATP $(5 \mu \mathrm{M})$, ADP $(5 \mu \mathrm{M})$, or PPi $(1 \mu \mathrm{M})$. Then, an appropriate concentration of ENPP1, PPase, or apyrase was added to the substrate solution and the fluorescence measurements were performed in real time using a spectrofluorometer (JASCO FP6500, Tokyo, Japan) with excitation wavelength of $488 \mathrm{~nm}$ and controlled temperature of $25^{\circ} \mathrm{C}$.

\subsection{Relative Activity of ENPP1, Apyrase, and PPase}

The relative activity of ENPP1 and apyrase was measured by addition of $5 \mu \mathrm{M}$ ATP to the solution of Kyoto Green $(1 \mu \mathrm{M})$ in $50 \mathrm{mM}$ HEPES buffer $(400 \mu \mathrm{L})$ containing $10 \mathrm{mM} \mathrm{NaCl}, 1 \mathrm{mM} \mathrm{MgCl}_{2}, \mathrm{pH}$ 7.4. The concentration of ENPP1 was fixed at $0.734 \mathrm{ng} / \mu \mathrm{L}$, while the concentrations of apyrase were varied from 5.0 to $12.5 \mathrm{ng} / \mu \mathrm{L}$. The fluorescence emission of Kyoto Green was recorded over time using a spectrofluorometer (JASCO FP6500, Tokyo, Japan) with excitation wavelength of $488 \mathrm{~nm}$ and controlled temperature of $25^{\circ} \mathrm{C}$.

The conversion of ATP to PPi by ENPP1, and then from PPi to Pi by PPase, was initiated by addition of $1.1 \mathrm{ng} / \mu \mathrm{L}$ of ENPP1 to the $50 \mu \mathrm{M}$ ATP buffer solution containing $50 \mathrm{mM}$ HEPES buffer $(100 \mu \mathrm{L}), 10 \mathrm{mM} \mathrm{NaCl}, 1 \mathrm{mM} \mathrm{MgCl}$, $\mathrm{pH}$ 7.4. The solution was incubated at $37^{\circ} \mathrm{C}$ for 0 and $1 \mathrm{~h}$. Then, the mixture was aliquoted in $20 \mu \mathrm{L}$ to the Kyoto Green $(1 \mu \mathrm{M})$ solution containing PPase $(0.03 \mathrm{ng} / \mu \mathrm{L})$ in $50 \mathrm{mM}$ HEPES buffer $(3 \mathrm{~mL}), \mathrm{pH}$ 7.4. Fluorescence emission of the Kyoto Green was measured as a time course at excitation wavelength of $488 \mathrm{~nm}$ and controlled temperature of $25^{\circ} \mathrm{C}$.

\subsection{PPi Accumulation Possibility in Biological Fluid}

The reaction mixture (RM) containing $1 \mathrm{mM}$ of each substrate (ATP, ADP and PPi) dissolved in $50 \mathrm{mM}$ HEPES buffer $(120 \mu \mathrm{L}), 1 \mathrm{mM} \mathrm{NaCl}, 2 \mathrm{mM} \mathrm{MgCl}_{2}$ was mixed with $30 \mu \mathrm{L}$ of the clear supernatant $\mathrm{SF}$ and then incubated at $37^{\circ} \mathrm{C}$ for $24 \mathrm{~h}$. The solution $(3 \mu \mathrm{L})$ was then aliquoted at 0 th and $24 \mathrm{th} \mathrm{h}$ of incubation and added to a solution of Kyoto Green $(1 \mu \mathrm{M})$ in $50 \mathrm{mM}$ HEPES buffer $(3 \mathrm{~mL})$, containing $10 \mathrm{mM} \mathrm{NaCl}, 1 \mathrm{mM} \mathrm{MgCl}$, to obtain fluorescence change of the RM and Kyoto Green at 0 and $24 \mathrm{~h}$.

To estimate the hydrolysis of each substrate (ATP, ADP, and PPi) at $0^{\text {th }}$ and $24^{\text {th }} \mathrm{h}$ of incubation with SF at $37^{\circ} \mathrm{C}, 30 \mu \mathrm{L}$ of RM was aliquoted and mixed with Kyoto Green $(1 \mu \mathrm{M})$ and apyrase $(0.33 \mathrm{ng} / \mu \mathrm{L})$ or PPase $(0.074 \mathrm{ng} / \mu \mathrm{L})$ in $50 \mathrm{mM}$ HEPES buffer $(3 \mathrm{~mL})$. The fluorescence changes of Kyoto Green were then recorded over time and the calculations performed according to Table 2. Data summarized in Table 3 was an average \pm SD of three individual replicates.

\section{Conclusions}

In summary, we report herein the application of a single fluorescent sensor, Kyoto Green, to real-time monitoring of ENPP1, apyrase, and PPase activity. These enzymes are key players in the ATP metabolic pathway, and their malfunctioning may culminate in an accumulation of PPi and development of CPPD in joints. Our novel methods show excellent performance in evaluation of the level of PPi formation, as well as the degree of conversion of ATP, ADP, and PPi to AMP and Pi in human and swine SF specimens. The analysis reveals that $16 \%$ of the SF samples demonstrated high propensity for PPi formation, and thus high risks of CPPD. Additionally, $47 \%$ of the samples displayed high rates of ADP dephosphorylation to AMP and Pi, which indicates no risk for CPPD. The conversion of PPi to Pi via TNAP in the SF, however, was comparatively low, as $89 \%$ of the samples displayed conversion percentage lower than $25 \%$. Future studies should evaluate the ability of our methods to assay SF samples from actual CPPD patients, confirmed cases of which are very rare due to the high uncertainty associated with CPPD diagnosis. 
Author Contributions: Conceptualization, J.W., T.T.; methodology, J.W., N.Y. and N.M.; software, N.M.; formal analysis, N.Y.; investigation, N.Y.; resources, T.T. and A.O.; writing-original draft preparation, J.W.; writing-review and editing, J.W.; visualization, N.Y. and J.W.; supervision, A.O. and I.H.; project administration, J.W.; funding acquisition, J.W. All authors have read and agreed to the published version of the manuscript.

Funding: We would like to acknowledge the financial support from the Center of Excellence on Medical Biotechnology (CEMB), S\&T Postgraduate Education and Research Development Office (PERDO), Office of Higher Education Commission (OHEC), Thailand. N.M. is also grateful to the RGJ Ph.D. Programme (PHD/1086/2557). This research was partially supported by the Faculty of Science, Mahidol University and the Thailand Research Fund (IRG5980001).

Acknowledgments: We acknowledge the Betagro Public Company, Banglen slaughter house, Nakhon Pathom, Thailand for the SF samples from healthy swine.

Conflicts of Interest: The authors declare no conflict of interest. The funders had no role in the design of the study; in the collection, analyses, or interpretation of data; in the writing of the manuscript, or in the decision to publish the results.

\section{References}

1. Mitrovic, D.R.; Stankovic, A.; Iriate-Borda, O.; Uzan, M.; Quintero, M.; Miravet, L.M.; Kuntz, D. The prevalence of chondrocalcinosis in the human knee joint. An autopsy study. J. Rheumatol. 1988, 15, 633-641. [PubMed]

2. Derfus, B.A.; Kurian, J.B.; Butler, J.J.; Daft, L.J.; Carrera, G.F.; Ryan, L.M.; Rosenthal, A.K. The high prevalence of pathologic calcium crystals in pre-operative knees. J. Rheumatol. 2002, 29, 570-574. [PubMed]

3. Rosenthal, A.K.; Ryan, L.M. Calcium Pyrophosphate Deposition Disease. N. Engl. J. Med. 2016, 374, 2575-2584. [CrossRef] [PubMed]

4. Costello, J.C.; Rosenthal, A.K.; Kurup, I.V.; Masuda, I.; Medhora, M.; Ryan, L.M. Parallel regulation of extracellular ATP and inorganic pyrophosphate: Roles of growth factors, transduction modulators, and ANK. Connect. Tissue Res. 2011, 52, 139-146. [CrossRef]

5. Rosenthal, A.K.; Gohr, C.M.; Mitton-Fitzgerald, E.; Lutz, M.K.; Dubyak, G.R.; Ryan, L.M. The progressive ankylosis gene product ANK regulates extracellular ATP levels in primary articular chondrocytes. Arthritis Res. Ther. 2013, 15, R154. [CrossRef]

6. Graff, R.D.; Lazarowski, E.R.; Banes, A.J.; Lee, G.M. ATP release by mechanically loaded porcine chondrons in pellet culture. Arthritis Rheum. 2000, 43, 1571-1579. [CrossRef]

7. Graff, R.D.; Picher, M.; Lee, G.M. Extracellular nucleotides, cartilage stress, and calcium crystal formation. Curr. Opin. Rheumatol. 2003, 15, 315-320. [CrossRef]

8. Yavorskyy, A.; Hernandez-Santana, A.; McCarthy, B.; McMahon, G. Detection of calcium phosphate crystals in the joint fluid of patients with osteoarthritis-analytical approaches and challenges. Analyst. 2008, 133, 302-318. [CrossRef]

9. Derfus, B.; Kranendonk, S.; Camacho, N.; Mandel, N.; Kushnaryov, V.; Lynch, K.; Ryan, L. Human osteoarthritic cartilage matrix vesicles generate both calcium pyrophosphate dihydrate and apatite in vitro. Calcif. Tissue Int. 1998, 63, 258-262. [CrossRef]

10. Derfus, A.B.; Rachow, W.J.; Mandel, S.N.; Boskey, L.A.; Buday, M.; Kushnaryov, M.V.; Ryan, M.L. Articular cartilage vesicles generate calcium pyrophosphate dihydrate like cystals in vitro. Arthritis Rheum. 1992, 35, 231-240. [CrossRef]

11. Xu, Y.; Cruz, T.F.; Pritzker, K.P. Alkaline phosphatase dissolves calcium pyrophosphate dihydrate crystals. J. Rheumatol. 1991, 18, 1606-1610. [PubMed]

12. Ojida, A.; Takashima, I.; Kohira, T.; Nonaka, H.; Hamachi, I. Turn-on fluorescence sensing of nucleoside polyphosphates using a xanthene-based Zn(II) complex chemosensor. J. Am. Chem. Soc. 2008, 130, 12095-12101. [CrossRef]

13. Ojida, A.; Miyahara, Y.; Wongkongkatep, J.; Tamaru, S.I.; Sada, K.; Hamachi, I. Design of dual-emission chemosensors for ratiometric detection of ATP derivatives. Chem. Asian J. 2006, 1, 555-563. [CrossRef]

14. Jingjing, Z.; Shizhi, Z.; Chaoqun, N.; Chen, L.; Jie, D.; Yong, C. A Label-Free Fluorescent DNA Calculator Based on Gold Nanoparticles for Sensitive Detection of ATP. Molecules 2018, 23, 2494.

15. Chaoqun, W.; Xin, Z.; Rui, L.; Zijin, Z.; Jianyu, H.; Yi, L. Isotopic core-satellites enable accurate and sensitive bioassay of adenosine triphosphate. Chem. Commun. 2019, 55, 10665-10668. 
16. Kohira, T.; Takashima, I.; Nonaka, H.; Ojida, A.; Hamachi, I. Real-time off/on-mode fluorescence assay for enzyme reactions involving nucleoside polyphosphates by use of a xanthene $\mathrm{Zn}^{\mathrm{II}}$-Dpa chemosensor. Chem. Lett. 2008, 37, 1164-1165. [CrossRef]

17. Qin, L.; Wang, X.; Liu, Y.; Wei, H. 2D-Metal-organic-framework-nanozyme sensor arrays for probing phosphates and their enzymatic hydrolysis. Anal. Chem. 2018, 90, 9983-9989. [CrossRef]

18. Huang, H.; Bai, J.; Li, J.; Lei, L.; Zhang, W.; Yan, S.; Li, Y. Fluorometric and colorimetric analysis of alkaline phosphatase activity based on a nucleotide coordinated copper ion mimicking polyphenol oxidase. J. Mater. Chem. B. 2019, 7, 6508-6514. [CrossRef]

19. Wongkongkatep, J.; Ojida, A.; Hamachi, I. Fluorescence sensing of inorganic phosphate and pyrophosphate using small molecular sensors and their applications. Top. Curr. Chem. 2017, 375, 30. [CrossRef]

20. Kurishita, Y.; Kohira, T.; Ojida, A.; Hamachi, I. Organelle-localizable fluorescent chemosensors for site-specific multicolor imaging of nucleoside polyphosphate dynamics in living cells. J. Am. Chem. Soc. 2012, 134, 18779-18789. [CrossRef]

21. Kittiloespaisan, E.; Ojida, A.; Hamachi, I.; Seetang-Nun, Y.; Kiatpathomchai, W.; Wongkongkatep, J. Label-free fluorescent detection of loop-mediated isothermal amplification of nucleic acid using pyrophosphate-selective xanthene-based Zn(II)-coordination chemosensor. Chem. Lett. 2012, 41, 1666-1668. [CrossRef]

22. Tiposoth, P.; Khamsakhon, S.; Ketsub, N.; Pongtharangkul, T.; Takashima, I.; Ojida, A.; Hamachi, I.; Wongkongkatep, J. Rapid and quantitative fluorescence detection of pathogenic spore-forming bacteria using a xanthene-Zn(II) complex chemosensor. Sens. Actuators B Chem. 2015, 209, 606-612. [CrossRef]

23. Melhorn, M.I.; Brodsky, A.S.; Estanislau, J.; Khoory, J.A.; Illigens, B.; Hamachi, I.; Kurishita, Y.; Fraser, A.D.; Nicholson-Weller, A.; Dolmatova, E.; et al. CR1-mediated ATP release by human red blood cells promotes CR1 clustering and modulates the immune transfer process. J. Biol. Chem. 2013, 288, 31139-31153. [CrossRef] [PubMed]

24. Zimmermann, H.; Zebisch, M.; Strauter, N. Cellular functions and molecular structure of ecto-nucleotidases. Purinergic Signal. 2012, 8, 437-502. [CrossRef] [PubMed]

25. Kawaguchi, M.; Han, X.; Hisada, T.; Nishikawa, S.; Kano, K.; Ieda, N.; Aoki, J.; Toyama, T.; Nakagawa, H. Development of an ENPP1 fluorescence probe for inhibitor screening, cellular Imaging, and prognostic assessment of malignant breast cancer. J. Med. Chem. 2019, 62, 9254-9269. [CrossRef]

26. Rachow, J.W.; Ryan, L.M. Partial characterization of synovial fluid nucleotide pyrophosphohydrolase. Arthritis Rheum. 1985, 28, 1377-1383. [CrossRef]

27. Lee, S.Y.; Levesque, S.A.; Sevigny, J.; Muller, C.E. A highly sensitive capillary electrophoresis method using $p$-nitrophenyl $5^{\prime}$-thymidine monophosphate as a substrate for the monitoring of nucleotide pyrophosphatase/phosphodiesterase activities. J. Chromatogr. B Analyt. Technol. Biomed. Life Sci. 2012, 911, 162-169. [CrossRef]

28. Namasivayam, V.; Lee, S.Y.; Muller, C.E. The promiscuous ectonucleotidase NPP1: Molecular insights into substrate binding and hydrolysis. Biochim. Biophys. Acta. 2017, 1861, 603-614. [CrossRef]

29. Lee, S.Y.; Sarkar, S.; Bhattarai, S.; Namasivayam, V.; De Jonghe, S.; Stephan, H.; Herdewijn, P.; El-Tayeb, A.; Muller, C.E. Substrate-Dependence of Competitive Nucleotide Pyrophosphatase/Phosphodiesterase1 (NPP1) Inhibitors. Front. Pharmacol. 2017, 8, 54. [CrossRef]

30. Zhang, X.; Chen, X.; Liu, K.; Zhang, Y.; Gao, G.; Huang, X.; Hou, S. Near-infrared ratiometric probe with a self-immolative spacer for rapid and sensitive detection of alkaline phosphatase activity and imaging in vivo. Anal. Chim. Acta. 2020, 1094, 113-121. [CrossRef]

31. Niu, X.; Ye, K.; Wang, L.; Lin, Y.; Du, D. A review on emerging principles and strategies for colorimetric and fluorescent detection of alkaline phosphatase activity. Anal. Chim. Acta. 2019, 1086, 29-45. [CrossRef] [PubMed]

32. Li, Y.; Xie, R.; Pang, X.; Zhou, Z.; Xu, H.; Gu, B.; Wu, C.; Li, H.; Zhang, Y. Aggregation-induced emission fluorescent probe for monitoring endogenous alkaline phosphatase in living cells. Talanta. 2019, 205, 120143. [CrossRef] [PubMed]

33. Jiang, G.; Zhu, W.; Chen, Q.; Shi, A.; Wu, Y.; Zhang, G.; Li, X.; Li, Y.; Fan, X. A new tetraphenylethylene based AIE sensor with light-up and tunable measuring range for adenosine triphosphate in aqueous solution and in living cells. Analyst. 2017, 142, 4388. [CrossRef] [PubMed] 
34. Ghale, G.; Nau, W.M. Dynamically analyte-responsive macrocyclic host-fluorophore systems. Acc. Chem. Res. 2014, 47, 2150-2159. [CrossRef] [PubMed]

35. Stefan, C.; Jansen, S.; Bollen, M. NPP-type ectophosphodiseterases: Unity in diversity. Trends Biochem. Sci. 2005, 30, 542-550. [CrossRef]

Sample Availability: Samples of Kyoto Green are available from A.O.

(C) 2020 by the authors. Licensee MDPI, Basel, Switzerland. This article is an open access article distributed under the terms and conditions of the Creative Commons Attribution (CC BY) license (http://creativecommons.org/licenses/by/4.0/). 